\title{
FORMATION OF INNOVATION EDUCATIONAL ENVIRONMENT AT HIGH SCHOOL
}

\author{
CKurdadze I., ORCID: 0000-0002-6870-857X, Dr., \\ Samtskhe-Javakheti State University, Akhaltsikhe, Georgia,irmak15@mail.ru

\section{ФОРМИРОВАНИЕ ИННОВАЦИОННОЙ ОБРАЗОВАТЕЛЬНОЙ СРЕДЫ В ВЫСШЕЙ ШКОЛЕ}

\author{
СКурдадзе И. Н., ORCID: 0000-0002-6870-857X, Dr., \\ Самихе-Джавахетский государственный университет, г. Ахалщихе, Грузия, irmak15@mail.ru
}

Abstract. The author, based on the achievements of phycological-pedagogical science, researches in the sphere of pedagogy at high school and pedagogical innovations, makes discussions on the theoretical-methodological and practical issues the of formation of innovative educational environment. The emphasis is made on the conditions promoting to formation of effective educational environment, the mechanisms required for its formation, need on planning and implementing the creative projects and a requirement on didactical system with two-level content of training discipline.

Аннотащия. Автор, опираясь на достижения психолого-педагогической науки, исследования в области педагогики в вузе и педагогические инновации, ведет дискуссии по теоретико-методологическим и практическим вопросам формирования инновационной образовательной среды. Акцент сделан на условиях, способствующих формированию эффективной образовательной среды, механизмах, необходимых для ее формирования, необходимости планирования и реализации творческих проектов и требованиях к дидактической системе с двухуровневым содержанием учебной дисциплины.

Keywords: innovative education, innovative educational environment, mechanism formation of innovative educational environment, creative projects, two-level content of training discipline.

Ключевые слова: инновационное образование, инновационная образовательная среда, механизм формирования инновационной образовательной среды, креативные проекты, двухуровневое содержание учебной дисциплины.

Before describing the meaning of 'Innovative Educational Environment', we considered it necessary to disclose the contemporary teachers' approach to the meaning of 'Innovative Education' in the preamble of the article.

At present conditions, characterized by globalization and informativeness, the new flexible and informational-technological paradigm of society is being created, which offers innovative development of all parts of society and hence, innovative thinking of its active individuals. The education system, being a strategic institute, gains the special importance in these conditions.

In the pedagogical innovators' (K. Angelovka, V. Zagvazinski, M. Klarin, N. Usufbekova, etc.) research works it is emphasized that innovative processes in edthe ucation promote creation of the new stage in interaction and development of scientific-pedagogical and pedagogical activities and adoption of their results. 
It should be particularly emphasized that in the development of innovative processes in the education system, there is tendency to be observed in liquidation of gaps between the processes of their perception, adequate assessment of mastering and using them in practice [4].

The innovative processes in the education system include the following three main processes: innovation creation, mastering and practicing. Moreover, creation of innovation in education system has its own peculiarities and is, partially, associated with a teacher's individualism, the feature of an educational institution, etc. The innovations in education are of particular character because the 'object' affected by the innovations is a live, developing, having the unique individuality personality.

It should be noted that researches on innovations in foreign pedagogy (A. Adams, J. Waseta, A. Nickols, etc.) have more pragmatic, hence, empirical character than those in our pedagogy. In such research works there are attempts not only to theoretically justify the innovations but to give practical advice in using the innovations in practice.

It should be noted that the innovation processes in the education became the object of deep research in the pedagogical literature only at the beginning of the current century. So, N. Lapin offers the systemic-creative concept of innovation by paying attention to different levels of their analysis: general-methodological, concrete-scientific, applicable — disclosing the structure of innovation processes, basic characteristics [7].

The processes of using the innovations in educational practice are of a special character. As per conclusions made by the didacts, the processes of objective assessment of innovative pedagogical experience by the science, on the one hand, and assessment and practicing of what is the pedagogical science is offering, on the other hand, are very complicated. Therefore, the concept of innovative environment, where the innovative processes are carried out, is of great importance for researches in innovative processes.

The research works by I. Glukhina, V. Zornova, V. Dela, E. Ignatyeva, A. Mudakhova, N. Usufoenov, etc. were used during studying the issue of formation and development of innovative educational environment at a high school. Besides, there were used the important methods of psychological-pedagogical researches (systemic-structural approach, analogy, synthesis, comparison, humane (person-oriented approach)).

When it comes to the meaning 'Innovative Educational Environment', attention should be made to its description given by V. Deli in his monography 'Formation and Development of Innovative Educational Environment in the Humanitarian High School' (2008): "Innovative Educational Environment is the educational space of the educational institution, unified with the corporative culture, complexly affecting development of a personality, promoting pedagogical activity in formation of untraditional way of thinking. Formation of innovative educational environment is achieved by cooperation of a teacher and a student — it is the general tendency for its formation and development which creates the innovative trajectory of teaching" [3].

The meaning 'Innovative Educational Environment' is discussed by the scientist teachers in internal and external aspects. The internal aspect is based on the idea of complex use of technicaltechnological and organizational-pedagogical innovations in the educational process (E. Ignateva, G. Roshe, V. Fokina, etc.), and the external aspect is based on integration of education, science and practice (V. Ivanova, Z. Sazonova, V. Surnin, etc.). Furthermore, the educational process is gaining the professional context promoting to use the knowledge in life and creating environment for new knowledges and innovations.

According to the specialists' point of view, the educational environment can be created under the following conditions: 
- Availability of the system of technical, programmed and telecommunication means (common database, library — information resources, modern e-learning environment, specialized websites, etc);

- Availability of the system for raising professional qualification, oriented on implementation of innovative teaching means and methods;

- Formation of the system of partnership between the high schools, scientific organizations and institutions.

We have extended the conclusions made by G. Beliakova, I. Geukhin, E. Merzon, A. Shabakova and other scientists and outlined the basic mechanisms for the formation of an innovative educational environment:

- Creating new and improving existing programmes for educating future specialists, additional teaching forms;

- Allowing the students studying the course chosen by them;

- Increasing the time for independent works on the basis of decreasing the time for auditory workload;

- Activating the programme of academic mobility;

- Developing e-learning means;

- Learning specialized courses, preparing course and diploma works;

- Involving the students in scientific-research and supplementary works;

- Formation of the integrated informational-analytical system of a high school enabling to collect, systemize and keep information;

- Developing communicative skills and tolerance by participating in several projects and exchange programmes;

- Formation of individual educational and professional trajectory [1].

It is impossible not to agree with the conclusion made by E. Merzon that one of the most task of the innovative educational environment is to allow the future specialist develop creative thinking, gain skills to catch and practice original ideas.

In the structure of professional training, important part should be given to the person's ability for self-improvement, development of creative potential, gaining experience, which is the most significant for self-realization of a person in professional activities. Hence, there is the need to identify the methods and means for activation and development of the personal and professional potential of students in the innovative educational environment.

Such methods and means should promote to formation of creative thinking during the professional training; this means training for gaining skills of independent works, research activities, motivation for self-improvement, implementation of innovative technologies (oriented fora a development of creative approach to professional activities) in educational programme [6].

According to L. Mergakhaeva, one of the most effective ways fan an or formation of innovative educational environment might be the drafting and implementing creative projects. Creative project is an independent creative work as a result of which the new product (programme, method, etc.) is developed by the author. Implementation of creative projects enable the students to discover and develop creative skills, manage the new challenges personally. The project method promotes to develop personality of students by involving them in several real professional activities. The project implementation promotes to using technologies for data collection, resolving constructive-technological tasks with informational technology [5].

Implementation of creative projects should promote to introduction of a new subject "Project Management" at a high school. The disciplines, related to several types of management, are in the 
great demand at current stage of education and business development and they might be serving as the most important aspect for development of innovative educational environment at high school [2].

According to E. Ignatiev, the new system of interaction "person-information-person", which is based on information exchange, is developing in the informational educational environment. The analysis of the informational-educational environment showed that it includes various didactical systems; furthermore, it initiates formation of other didactical systems [4]. Specifically, this is related to a high school system (complicated communicative) based on information exchange processes in the "person-information-person" system. Such system promotes to the teachers and students' joint involvement in planning of education project as well in assessment of its outcome. Such approach enables changing the emphasis in teachers' activities (increasing the consulting role, organizational, motivative functions of the teacher and decreasing their role of being informative and leading the education process) and giving a student initiative for making a choice.

The didactical system with two-level content training discipline should be established at the modern high school - invariable part, which is projected by a teacher (basic) and variable part which is projected by a student using the materials from the common information space (according to his/her interests, needs, motivation, personal experience). Information exchange takes place during the direct interaction in the education process.

\section{References:}

1. Belyakov, G. P., \& Kaup, V. E. (2012). Development and stimulating of innovation activity in higher educational institutions. Problems of the modern economy, (4), 397-400.

2. Strongin, R., \& Grudzinskii, A. (2008). Proektno-orientirovannoe upravlenie innovatsionnym universitetom. Vysshee obrazovanie v Rossii, (4), 26-31.

3. Deliya, V. P. (2008). Formirovanie i razvitie innovatsionnoi obrazovatel'noi sredy gumanitarnogo vuza.

4. Ignat'eva, E. Yu. (2007). Kompetentnostnyi podkhod v menedzhmente znanii vuza. Integratsiya obrazovaniya, (1). 35-40

5. Torkunova, J. V., Khairullina, E. R., Komelina, V. A., Volkova, N. V., \& Ponomarev, K. N. (2014). The peculiarities of qualitative information, analytical maintenance innovative and educational activity technological projection in higher educational institution. Life Science Journal, $11(8), 498-503$.

6. Virtanen, M. A., Haavisto, E., Liikanen, E., \& Kääriäinen, M. (2018). Ubiquitous learning environments in higher education: A scoping literature review. Education and Information Technologies, 23(2), 985-998.

7. Rashevska, N., \& Tkachuk, V. (2018). Technological conditions of mobile learning in high school. arXiv preprint arXiv:1808.01989.

\section{Список литературьи:}

1. Беляков Г. П., Кауп В. Э. Развитие и стимулирование инновационной деятельности высших учебных заведений // Проблемы современной экономики. 2012. №4. С. 397-400.

2. Стронгин Р., Грудзинский А. Проектно-ориентированное управление инновационным университетом // Высшее образование в России. 2008. №4. С. 26-31.

3. Делия В. П. Формирование и развитие инновационной образовательной среды гуманитарного вуза. М.: ИСЭПиМ, 2008. 480 с.

4. Игнатьева Е. Ю. Компетентностный подход в менеджменте знаний вуза // Интеграция образования. 2007. №1. С. 35-40. 
5. Torkunova J. V. et al. The peculiarities of qualitative information, analytical maintenance innovative and educational activity technological projection in higher educational institution // Life Science Journal. 2014. V. 11. №8. P. 498-503.

6. Virtanen M. A. et al. Ubiquitous learning environments in higher education: A scoping literature review // Education and Information Technologies. 2018. V. 23. №2. P. 985-998.

7. Rashevska N., Tkachuk V. Technological conditions of mobile learning in high school // arXiv preprint arXiv:1808.01989. 2018.

Работа поступила

в редакиию 11.03.2019 2.
Принята к публикациии 15.03.2019 2.

Cite as (APA):

Kurdadze, I. (2019). Formation of Innovation Educational Environment at High School. Bulletin of Science and Practice, 5(4), 405-409. https://doi.org/10.33619/2414-2948/41/58.

Ссылка для циитирования:

Kurdadze I. Formation of Innovation Educational Environment at High School // Бюллетень науки и практики. 2019. Т. 5. №4. С. 405-409. https://doi.org/10.33619/2414-2948/41/58. 